\title{
Correlation between Auditory Brainstem Response Characteristics and Hearing Recovery in Sudden Deafness
}

\author{
Eun Jung Lim, JooHyun Shin, Tae Hoon Kim, Jun Ho Park, and SungHee Kim \\ Department of Otolaryngology-Head and Neck Surgery, Daegu Fatima Hospital, Daegu, Korea
}

\section{돌발성 난청에서 청성뇌간반응검사의 예후인자로서의 의미}

임은정 · 신주현 · 김태훈 · 박준호 · 김성희

대구 파티마병원 이비인후과

\author{
Received December 2, 2018 \\ Revised March 19, 2019 \\ Accepted March 22, 2019 \\ Address for correspondence \\ SungHee Kim, PhD \\ Department of Otolaryngology- \\ Head and Neck Surgery, \\ Daegu Fatima Hospital, \\ 183 Ayang-ro, Dong-gu, \\ Daegu 41184, Korea \\ Tel +82-53-940-7353 \\ Fax +82-53-940-7417 \\ E-mail sungheekim@fatima.or.kr
}

Background and Objectives Auditory brainstem response (ABR) can be utilized to verify the hearing threshold and determine the existence of retrocochlear pathology in sudden deafness. However, little is known about the significance of ABR characteristics as a prognostic factor in sudden deafness. The purpose of this study is to evaluate which characteristics of ABR is associated with the prognosis of sudden deafness.

Subjects and Method We studied patients who were diagnosed with unilateral sudden deafness from January 2017 to May 2018. ABR results of click stimuli at 90 dB nHL were analyzed by the latency of wave I, III, and V.

Results A total of 113 patients (55 men and 58 women) participated in the study. Hearing recovery was observed in 94 cases (83.2\%). The absolute latency of wave I, III, and V was prolonged in the affected ears when compared with the unaffected ears. Hearing improvement was only correlated to the interaural latency delay of wave I (Pearson's $\mathrm{r}=-0.278, p<0.05$ ). Prolonged interaural latency delay was noted from complete toward slight hearing recovery group. When the hearing outcome was evaluated by the interaural latency delay of wave I at $0.2 \mathrm{~ms}$, the result of under $0.2 \mathrm{~ms}$ was significantly better than that over $0.2 \mathrm{~ms}$ and no visible wave I.

Conclusion Prolonged interaural delay of wave I over $0.2 \mathrm{~ms}$ and no visible wave I in ABR showed worse hearing outcome in sudden deafness. This finding may provide ABR as a potential prognostic indicator in sudden deafness.

Korean J Otorhinolaryngol-Head Neck Surg 2019;62(8):435-41

Key Words Auditory · Evoked potentials · Latency.

\section{서 론}

청성뇌간반응검사(auditory brainstem response, $\mathrm{ABR}$ )는 돌발성 난청 환자에서 청력역치를 예측하고 후미로성 병변을 확인하기 위해 주로 시행되고 있다. ${ }^{1)}$ 한편, $\mathrm{ABR}$ 검사가 돌발

This is an Open Access article distributed under the terms of the Creative Commons Attribution Non-Commercial License (https://creativecommons.org/licenses/by-nc/4.0) which permits unrestricted non-commercial use, distribution, and reproduction in any medium, provided the original work is properly cited.
성 난청 환자의 치료 경과 및 예후를 예측하는 인자로서 유 용한지에 대해서도 몇몇 연구가 발표되었는데 $\mathrm{ABR}$ 검사상 비정상 소견을 보이는 환자군에서 더 낮은 자연회복률 및 스 테로이드 치료에 더 낮은 치료반응을 보고한 연구가 있었으 ${ }^{220,3)} \mathrm{ABR}$ 검사의 I파의 절대 잠복기가 돌발성 난청의 예후 에 관련된다는 연구가 보고되었다. ${ }^{4)}$ 이들은 돌발성 난청에서 $\mathrm{ABR}$ 검사가 예후인자가 될 수 있음에 대한 가능성은 제시하 였으나 구체적인 연구들은 부족한 실정이다. 
이에 저자들은 돌발성 난청 환자의 $\mathrm{ABR}$ 검사를 후향적으 로 분석하여 $\mathrm{ABR}$ 검사에서 비교적 안정된 파형을 보이는 I, $\mathrm{III}, \mathrm{V}$ 파형의 잠복기가 돌발성 난청 환자의 청력호전 정도에 관련이 있는지, 관련이 있다면 어떤 $\mathrm{ABR}$ 파형 특성이 돌발 성 난청의 예후를 예측하는 인자인지 알아보고자 하였다.

\section{대상 및 방법}

본 연구는 2017년 1월부터 2018년 5월까지 대구파티마병 원 이비인후과에서 돌발성 난청으로 진단되어 입원치료를 받 은 총 228명을 대상으로 후향적 연구를 시행하였다. 모든 환 자들은 3 일 이내에 연속된 3 개의 주파수에서 $30 \mathrm{~dB}$ 이상의 갑작스러운 청력저하를 보이는 돌발성 난청의 기준을 만족하 였다. 이 중 메니에르씨병, 재발성 또는 양측성 돌발성 난청, 소뇌교각종양 등의 병력이 있거나 중이염 또는 병변귀가 유일 청인 경우를 제외하였다. 또한 발병 후 2주가 지나 병원을 방 문하였거나 치료 후 경과 관찰이 1 개월 이상 되지 않은 환자, 입원기간 중 $\mathrm{ABR}$ 검사를 시행하지 않은 환자를 제외하여 총 113 명의 환자를 대상으로 통계적 분석을 시행하였다.

돌발성 난청으로 입원한 모든 환자들은 7일간 입원치료를 하였으며 Dexamethasone(Dexamethasone sodium phosphate $5 \mathrm{mg} / \mathrm{mL}$, Yuhan Corp., Seoul, Korea)을 하루 2회 정맥주사하였으며 이후 퇴원하여 7일에 걸쳐 경구 스테로이 드인 Solondo(Prednisolone $5 \mathrm{mg}$, Yuhan Corp.)를 $30 \mathrm{mg} /$ day 4일, $15 \mathrm{mg} /$ day 3 일로 감량하여 치료하였다. 통증의학 과에서 성상신경차단술을 하루 1 회씩 시행하여 입원기간 동 안 최소 5 회 이상 시행하였으며 Carbogen $\left(5 \% \mathrm{CO}_{2}\right.$ 와 $95 \%$ $\mathrm{O}_{2}$ 로 구성된 혼합가스)을 입원기간 동안 1일 8회, 1 시간 간격 으로 30 분씩 흡입하도록 하였다. ${ }^{5)}$ 고실 내 스테로이드 주입 술은 Dexamethasone(Dexamethasone sodium phosphate $5 \mathrm{mg} / \mathrm{mL}$ )를 사용하여 1주일에 2회씩 총 4회 시행하였다.

청력검사는 치료 전 초기 순음청력도와 치료 후 1 개월이 경과한 시점의 순음청력도를 기준으로 청력역치를 평가하였 다. 추적 청력검사를 치료 후 1 개월과 3 개월째 검사를 권유하 였으나, 치료 후 3개월째 추적되지 않은 경우가 다수 있어 본 연구에서는 비교적 청력이 안정화되었다고 판단되는 치료 후 1 개월째 청력결과를 사용하였다. 평균청력은 $0.5,1,2,4 \mathrm{kHz}$ 를 4분법으로 평균하였다.

$\mathrm{ABR}$ 검사는 방음실(Industrial Acoustics Company, INC., Model 40A, Bronx, NY, USA)에서 모든 대상 환자들은 움 직임을 최소화한 상태에서 진행되었다. $\mathrm{ABR}$ 검사는 GSI Audera(Grason-Stadler, Madison, WI, USA)를 이용해 검 사가 진행되었으며 검사의 자극음은 Click음을 이용하였고
기도 자극음의 극성(polarity)은 희박상(rarefaction)으로 $11.1 \mathrm{~Hz}$ 의 자극을 주었다. Time window는 10 millisecond 로 설정되었으며 전위의 증폭기는 10 만 배로 반응을 증폭하 여 기록하였다. $90 \mathrm{~dB} n H L$ 의 상역치 강도에서 최소 2회의 파형을 기록하였다.

치료 전후 청력호전 정도는 초기 청력의 평균값에서 치료 후 청력의 평균값을 뺀 값으로 정하였다. 또한 Siegel이 제시 한 판정표를 기준으로 최종 $25 \mathrm{~dB}$ 역치 이내로 청력호전이 있는 경우를 완전회복(grade I), $15 \mathrm{~dB}$ 이상 청력호전이 있고 최종 청력이 25 45 dB 범위의 청력역치인 경우를 부분회복 (grade II), $15 \mathrm{~dB}$ 이상 청력호전이 있고 최종 $45 \mathrm{~dB}$ 초과의 청력역치인 경우를 경도회복(grade $\mathrm{III}), 15 \mathrm{~dB}$ 미만으로 청 력호전이 있거나 최종 $75 \mathrm{~dB}$ 이상 청력역치인 경우를 불변 (grade IV)으로 구분하였다.

통계분석은 paired t-test를 사용하여 병변 측과 건 측의 $\mathrm{ABR}$ 검사상 I, III, V 파형의 절대 잠복기 및 파 간 잠복기를 비교하였다. 난청 정도에 따른 $\mathrm{ABR}$ 파형의 존재 유무와 초 기 난청 정도가 파형의 절대 잠복기에 영향이 있는지 알아보 기 위해 카이제곱 검증과 one-way analysis of variance (ANOVA) 검증을 하였다. Siegel의 분류에 의한 청력회복 정 도에 따른 네 군 간에 $\mathrm{ABR}$ 파형의 절대 잠복기, 파 간 잠복기, 양이 간 잠복기 지연을 비교하기 위하여 one-way ANOVA를 시행하였다. 청력호전 정도와 관련성을 보이는 인자를 알아 보기 위해 correlation test를 시행하였으며, 초기 청력과의 관 련성도 함께 살펴보았다. 또한 청력호전 정도와 관련된 $\mathrm{ABR}$ 파형 특성이 Siegel의 회복 정도로 분류한 네 군 간에서 차이 를 보이는지 카이제곱 검증을 이용하여 분석하였다. PASW statistics 18 version(SPSS Inc., Chicago, IL, USA)을 이용하 였으며 통계학적 유의수준은 $95 \%$ 이상 $(p<0.05)$ 으로 하였다.

본 후향적 연구는 헬싱키 선언에 따라, 기관윤리심의위원회 의 승인(DFE18ORIO037)를 받았다.

\section{결 과}

최종 해당된 환자는 총 113 명으로 이들 중 남자는 55 명 (48.7\%), 여자는 58명(51.3\%)이었으며 평균나이는 54.1세로 10세부터 81세까지 다양하게 분포하였다.

초기 평균청력은 $78.84 \pm 22.00 \mathrm{~dB} \mathrm{HL}$ 이었으며, 돌발성 난 청이 발병하여 치료 시작까지의 기간은 $3.96 \pm 2.93$ 일이었다. 최종 평균청력이 평가된 시점은 치료가 종결된 후 평균 27.10 \pm 10.10 일에 시행되었으며, 최종 청력은 $45.58 \pm 26.1 \mathrm{~dB} \mathrm{HL}$, 호전 정도는 $33.27 \pm 21.03 \mathrm{~dB}$ 이었다. $\mathrm{ABR}$ 의 측정 시점은 돌 발성 난청으로 진단된 첫 검사일로부터 평균 $2.44 \pm 2.02$ 일에 
시행되었다.

실제 환자에서 시행한 $\mathrm{ABR}$ 결과를 Fig. 1에 제시하였다. 두 증례는 모두 좌측의 돌발성 난청 환자로 건 측은 정상청 력이며, 병변 측은 중등고도 난청으로 첫 번째 증례는 파형 의 지연이, 두 번째 증례는 파형의 지연이 관찰되지 않았다. 파형의 지연이 없었던 두 번째 증례의 경우 정상청력으로 회 복되었다.

전체 환자에서 $\mathrm{ABR}$ 검사상 병변 측과 건 측의 상역치 자 극인 $90 \mathrm{dBn} \mathrm{HL}$ 에서 I, III, V파의 절대 잠복기 및 파 간 잠 복기를 분석하였다. I, III, V파의 절대 잠복기는 병변 측이 각 각 $1.85 \pm 0.43 \mathrm{~ms}, 4.08 \pm 0.48 \mathrm{~ms}, 6.03 \pm 0.64 \mathrm{~ms}$ 이었으며 건 측은 $1.76 \pm 0.43 \mathrm{~ms}, 3.97 \pm 0.45 \mathrm{~ms}, 5.81 \pm 0.44 \mathrm{~ms}$ 으로 통계 적으로 유의하게 병변 측에서 파형이 지연되었다(paired ttest, $p<0.05)$. 그러나 I-III, I-V, III-V파 간의 잠복기는 병 변 측과 건 측 간에 통계적으로 유의한 차이를 보이지 않았다 (Table 1).

$\mathrm{ABR}$ 파형의 분석에 있어 돌발성 난청의 초기 청력 상태에

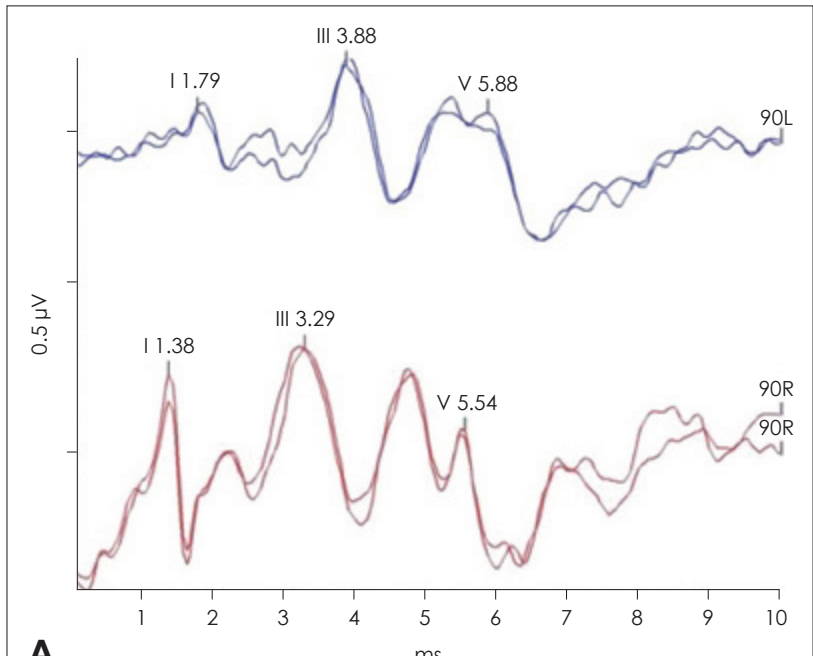

의한 영향이 있는지 알아보기 위해 초기 청력의 정도를 중등 도 난청 $(\leq 55 \mathrm{~dB})$, 중등고도 난청 $(\leq 70 \mathrm{~dB})$, 고도 난청 $(\leq 90$ $\mathrm{dB})$, 농 $(>90 \mathrm{~dB})$ 으로 분류하였고, 파형의 소실율의 정도를 교차분석을 시행하였다(Table 2). 난청이 심할수록 $\mathrm{ABR}$ 파 형의 소실율이 증가하였는데 교차분석 결과상 I, III, V 파형 에 대해 각각 $\chi^{2}=31.764, p<0.001, \chi^{2}=27.220, p<0.001, \chi^{2}=$ $17.546, p<0.001$ 로 의미가 있었다. 그러나, $90 \mathrm{~dB}$ 을 초과하 는 난청군을 배제하였을 때 난청이 심할수록 $\mathrm{ABR}$ 파형의 소실율이 증가하지 않았으며 I, III, V 파형의 통계값은 각각 $\chi^{2}=2.257, p=0.133, \chi^{2}=1.936, p=0.164, \chi^{2}=1.787, p=0.181$ 으로 의미가 없었다.

초기 청력 정도에 따라 I, III, V파의 절대 잠복기를 oneway ANOVA 검증하였을 때 I파의 경우 초기 청력 정도에 따른 잠복기의 상관관계를 보이지 않았으며 III, V파의 경우 초기 청력이 나쁠수록 잠복기가 유의하게 연장되는 소견을 보였다(Table 3). 사후분석 결과에서는 I, III파에서는 난청 정도에 따른 군 간의 차이는 없었으나, $\mathrm{V}$ 파에서 농인 경우에

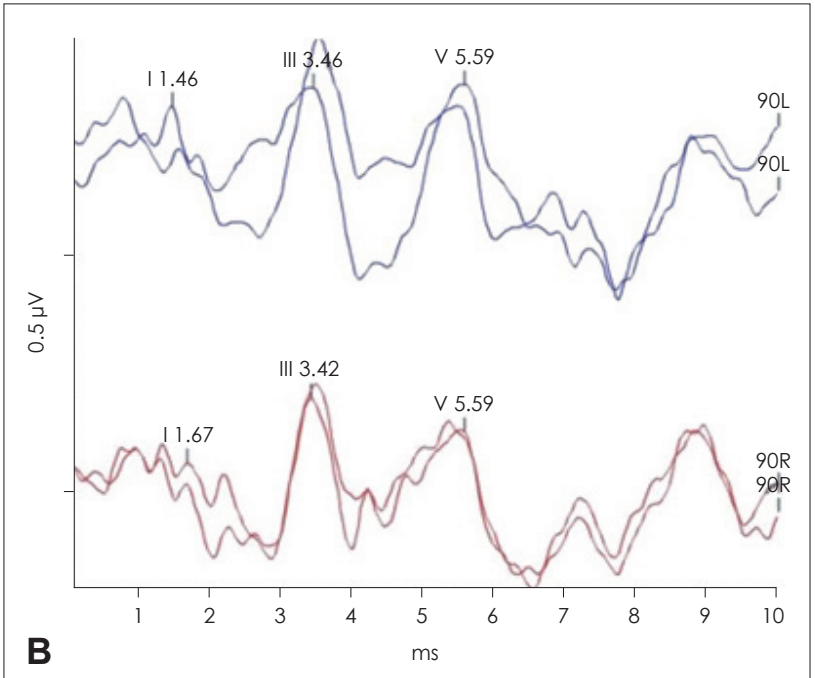

Fig. 1. ABR findings of two cases. $A B R$ of 59 -year-old female patient with $63 \mathrm{~dB}$ flap type hearing loss (the average of $0.5,1,2$, and 4 $\mathrm{kHz}$ ) in her left ear (A). Interaural latency delays of wave I, III, and $\mathrm{V}$ were more than $0.3 \mathrm{~ms}$. Her final hearing did not recover without any brain lesion in the brain MRI. ABR of 45-year-old male patient with $68.7 \mathrm{~dB}$ flap type hearing loss in his left ear (B). Interaural latency delay was not found in every wave. He recovered to normal hearing level. ABR: auditory brainstem response.

Table 1. Comparison of ABR characteristics between the affected and unaffected ears in all patients with sudden hearing loss

\begin{tabular}{lccccccc}
\hline & Affected ear & $\mathrm{n}$ & Missing (\%) & Unaffected ear & $\mathrm{n}$ & Missing (\%) & $\mathrm{p}$-value \\
\hline Absolute latency (ms) & & & & & & & \\
$\quad$ Wave I & $1.85 \pm 0.43$ & 62 & 45.1 & $1.76 \pm 0.43$ & 92 & 18.6 & $<0.001$ \\
$\quad$ Wave III & $4.08 \pm 0.48$ & 71 & 37.2 & $3.97 \pm 0.45$ & 103 & 8.8 & $<0.001$ \\
$\quad$ Wave V & $6.03 \pm 0.64$ & 99 & 12.4 & $5.81 \pm 0.44$ & 113 & 0.0 & $<0.001$ \\
$\begin{array}{l}\text { Interpeak latency (ms) } \\
\text { I-III }\end{array}$ & $2.11 \pm 0.23$ & 58 & 48.7 & $2.21 \pm 0.37$ & 91 & 19.5 & $\mathrm{~ns}$ \\
III-V & $1.83 \pm 0.33$ & 71 & 37.2 & $1.82 \pm 0.28$ & 103 & 8.8 & $\mathrm{~ns}$ \\
I-V & $3.97 \pm 0.41$ & 62 & 45.1 & $4.05 \pm 0.45$ & 94 & 16.8 & $\mathrm{~ns}$ \\
\hline
\end{tabular}

ABR: auditory brainstem response 
서만 잠복기 지연이 $90 \mathrm{~dB}$ 이하의 난청군과 비교하여 유의하 게 길었다.

$\mathrm{ABR}$ 검사의 파형 특성들이 Siegel의 분류에 의한 청력회

Table 2. Cross tabulation of the presence or absence of waves of $A B R$ according to initial hearing level

\begin{tabular}{lccc}
\hline \multirow{2}{*}{$\begin{array}{c}\text { Group of } \\
\text { the initial HL }\end{array}$} & \multicolumn{2}{c}{ Wave status (\%) } & Total \\
\cline { 2 - 3 } Wave I & Presence & Absence & \\
$\leq 55 \mathrm{~dB} \mathrm{HL}$ & $15(83.3)$ & $3(16.7)$ & 18 \\
$\leq 70 \mathrm{~dB} \mathrm{HL}$ & $19(79.2)$ & $5(20.8)$ & 24 \\
$\leq 90 \mathrm{~dB} \mathrm{HL}$ & $25(65.8)$ & $13(34.2)$ & 38 \\
$>90 \mathrm{~dB} \mathrm{HL}$ & $3(9.1)$ & $30(90.9)$ & 33 \\
\hline Total & $62(54.9)$ & $51(45.1)$ & 113 \\
\hline Wave III & & & \\
$\leq 55 \mathrm{~dB} \mathrm{HL}$ & $16(88.9)$ & $2(11.1)$ & 18 \\
$\leq 70 \mathrm{~dB} \mathrm{HL}$ & $20(83.3)$ & $4(16.7)$ & 24 \\
$\leq 90 \mathrm{~dB} \mathrm{HL}$ & $28(73.7)$ & $10(26.3)$ & 38 \\
$>90 \mathrm{~dB} \mathrm{HL}$ & $7(21.2)$ & $26(78.8)$ & 33 \\
\hline Total & $71(62.8)$ & $42(37.2)$ & 113 \\
\hline Wave V & & & \\
$\leq 55 \mathrm{~dB} \mathrm{HL}$ & $18(100.0)$ & $0(0.0)$ & 18 \\
$\leq 70 \mathrm{~dB} \mathrm{HL}$ & $24(100.0)$ & $0(0.0)$ & 24 \\
$\leq 90 \mathrm{~dB} \mathrm{HL}$ & $36(94.7)$ & $2(5.3)$ & 38 \\
$>90 \mathrm{~dB} \mathrm{HL}$ & $21(63.6)$ & $12(36.4)$ & 33 \\
\hline Total & $99(87.6)$ & $14(12.4)$ & 113 \\
\hline ABR & & &
\end{tabular}

ABR: auditory brainstem response

Table 3. Comparison of absolute latency (ms) of each wave according to initial hearing level

\begin{tabular}{llll} 
& Initial hearing level \\
\hline$\leq 55 \mathrm{~dB}$ & $\leq 70 \mathrm{~dB} \quad \leq 90 \mathrm{~dB} \quad>90 \mathrm{~dB}$ & -value
\end{tabular}

Wave I $1.82 \pm 0.38 \quad 1.71 \pm 0.34 \quad 1.98 \pm 0.52 \quad 1.85 \pm 0.22 \quad$ ns

Wave III $3.91 \pm 0.393 .94 \pm 0.45 \quad 4.18 \pm 0.79 \quad 4.50 \pm 0.53<0.05$

Wave V $5.81 \pm 0.36 \quad 5.87 \pm 0.545 .95 \pm 0.63 \quad 6.53 \pm 0.71<0.001$
복 정도에 따른 완전회복, 부분회복, 경도회복, 불변군에서 차이가 있는지 one-way ANOVA 검증을 한 결과, 완전회복 에서 경도회복으로 갈수록 병변 측의 III과 V파의 절대 잠복 기가 지연되고 $(p<0.05$ 와 $p<0.01)$, I과 $\mathrm{V}$ 파의 양이 간 잠복 기 지연이 길어지는 경향을 보였다 $(p<0.05$ 와 $p<0.01)$ (Table 4).

돌발성 난청의 다양한 예후 인자들과 청력호전 정도와의 상관분석을 하였을 때 본 연구에서는 나이(Pearson $\mathrm{r}=-0.901$ ) 및 치료개시 시간 $(\mathrm{r}=-0.164)$ 은 유의한 상관관계를 보이지 않 았으며 발병 시 청력이 나쁠수록 오히려 청력호전 정도가 유 의하게 높았다 $(\mathrm{r}=0.263, p<0.01) . \mathrm{ABR}$ 파형과 초기 난청 정 도 간의 상관분석상에는 초기 청력이 나쁠수록 III과 V파의 절대 잠복기와(Pearson $\mathrm{r}=0.353, p<0.01$ 과 $\mathrm{r}=0.340, p<0.01$ ) $\mathrm{III}$ 과 V파의 양이 간 잠복기 지연 정도가 $(\mathrm{r}=0.396, p<0.01$ 과 $\mathrm{r}=0.400, p<0.01)$ 유의하게 컸다(Table 5).

초기 청력과 I파의 절대 잠복기(Pearson $\mathrm{r}=0.116, p>0.05$ ) 및 양이 간 잠복기 지연 정도(Pearson $\mathrm{r}=0.049, p>0.05$ )는 상 관관계를 보이지 않았으나 청력호전 정도와의 상관관계를 분석한 결과 I파의 양이 간 잠복기 지연이 유일하게 통계적 으로 유의한 상관관계를 보였다(r=-0.278, $p>0.05$ )(Table 5, Fig. 2).

I파의 양이 간 잠복기 지연은 Siegel의 청력회복군에 따른 one-way ANOVA 분석에서 청력회복 정도와 관련이 있었 고, 상관분석에서도 청력호전 정도와 유일하게 통계적으로 유의한 상관관계를 보여 결국 I파의 파형이 관찰되는 경우에 는 I파의 양이 간 잠복기 지연이 청력호전 정도와 유의한 상 관관계가 있음을 추론할 수 있다. 상관분석 결과를 볼 때, 청 력호전에 따른 네 군 간의 one-way ANOVA 검증 결과에서 유의미했던 병변 측의 III과 $\mathrm{V}$ 파의 절대 잠복기와 $\mathrm{V}$ 파의 양이 간 잠복기 지연은 초기 청력과 관련이 있는 인자로 보여진다.

Table 4. ABR characteristics in groups of hearing recovery by Siegel's classification and group comparison using one-way ANOVA

\begin{tabular}{|c|c|c|c|c|c|}
\hline & $\begin{array}{c}\text { Complete recovery } \\
(n=32)\end{array}$ & $\begin{array}{l}\text { Partial recovery } \\
\qquad(n=27)\end{array}$ & $\begin{array}{l}\text { Slight recovery } \\
(n=35)\end{array}$ & $\begin{array}{l}\text { No recovery } \\
(n=19)\end{array}$ & p-value \\
\hline \multicolumn{6}{|c|}{ Absolute latency (ms) of the affected ear } \\
\hline Wave I & $1.75 \pm 0.42$ & $1.90 \pm 0.42$ & $2.01 \pm 0.44$ & $2.04 \pm 0.41$ & ns \\
\hline Wave III & $4.01 \pm 0.45$ & $3.99 \pm 0.46$ & $4.28 \pm 0.50$ & $4.24 \pm 0.48$ & $<0.05$ \\
\hline Wave $\mathrm{V}$ & $5.84 \pm 0.54$ & $5.94 \pm 0.49$ & $6.41 \pm 0.71$ & $6.01 \pm 0.62$ & $<0.01$ \\
\hline \multicolumn{6}{|c|}{ Interpeak latency (ms) of the affected ear } \\
\hline I-III & $2.16 \pm 0.20$ & $2.09 \pm 0.24$ & $2.02 \pm 0.30$ & $2.06 \pm 0.25$ & ns \\
\hline $\mid I I-V$ & $1.82 \pm 0.26$ & $1.93 \pm 0.25$ & $1.86 \pm 0.25$ & $1.79 \pm 0.52$ & ns \\
\hline$I-V$ & $4.02 \pm 0.28$ & $4.01 \pm 0.28$ & $3.88 \pm 0.55$ & $3.83 \pm 0.76$ & ns \\
\hline \multicolumn{6}{|c|}{ Interaural latency delay (IAD) (ms) } \\
\hline$|A D|$ & $0.05 \pm 0.18$ & $0.23 \pm 0.27$ & $0.29 \pm 0.36$ & $0.22 \pm 0.37$ & $<0.05$ \\
\hline$|A D|||$ & $0.05 \pm 0.18$ & $0.08 \pm 0.22$ & $0.20 \pm 0.32$ & $0.15 \pm 0.24$ & ns \\
\hline IAD V & $0.17 \pm 0.33$ & $0.16 \pm 0.31$ & $0.48 \pm 0.49$ & $0.06 \pm 0.61$ & $<0.01$ \\
\hline
\end{tabular}

ABR: auditory brainstem response, ANOVA: analysis of variance 
그러나, I파의 경우 파형이 소실된 경우가 많아 분석요인으 로 고려하기 위해 비연속 변수로 I파를 분류할 필요가 있다. $\mathrm{V}$ 파의 양이 간 차이가 $0.2 \mathrm{~ms}$ 혹은 $0.4 \mathrm{~ms}$ 보다 큰 경우 정 상범위가 아닌 것으로 보고하고 있기에 ${ }^{6-8)}$ 저자들은 I파의 양이 간 지연이 $0.2 \mathrm{~ms}$ 이하의 경우 지연이 없는 경우로, 0.2 $\mathrm{ms}$ 보다 초과하는 경우 지연이 뚜렷한 경우로 판단하였고, 이를 I 파형이 소실된 경우와 함께 고려하여 비교해 보았다.

I파의 양이 간 잠복기 지연이 있거나 I파 소실의 경우 $\mathrm{Sie}^{-}$ gel의 분류에 의한 청력회복군 간에 통계적으로 유의한 차이 가 있었다 $\left(\chi^{2}=42.093, p<0.001\right)$. 완전회복의 경우 I파의 양이 간 잠복기 지연이 없는 경우 $(\geq 0.2 \mathrm{~ms})$ 가 $71.9 \%$, 지연이 있는 경우 $(<0.2 \mathrm{~ms})$ 가 $15.6 \%$, I파의 소실이 $12.5 \%$ 로 I파의 양이 간 잠복기 지연이 없는 경우가 많았다. I파의 양이 간 잠복기 지연이 없는 경우 완전회복의 $71.9 \%$, 부분회복의 $48.2 \%$, 경 도회복의 $5.7 \%$ 를 차지하였다. I 파형의 소실의 경우 완전회

Table 5. Correlation analysis between hearing results (initial hearing and hearing gain) and age, onset, initial hearing level and ABR characteristics

\begin{tabular}{lcc}
\hline \multicolumn{1}{c}{ Pearson's $r$} & Initial hearing & Hearing gain \\
\hline Age & $0.201^{*}$ & -0.901 \\
Onset & -0.043 & -0.164 \\
Initial hearing & 1 & $0.263^{\dagger}$ \\
ABR characteristics & & \\
Wave I & 0.116 & -0.231 \\
Wave III & $0.353^{\dagger}$ & -0.106 \\
Wave V & $0.340^{\dagger}$ & 0.021 \\
IAD I & 0.049 & $-0.278^{*}$ \\
IAD III & $0.396^{\dagger}$ & -0.042 \\
IAD V & $0.400^{\dagger}$ & 0.175
\end{tabular}

$* p<0.05,+p<0.01$, respectively. IAD: interaural latency delay, ABR: auditory brainstem response

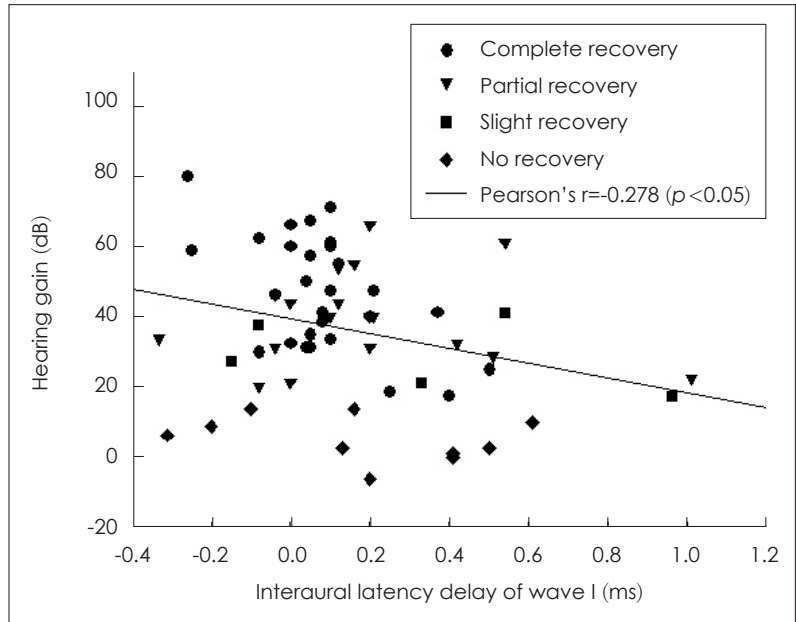

Fig. 2. Correlation of interaural latency delay of wave I and hearing gain. The hearing gain was negatively correlated as the interaural latency of wave I delayed $(r=-0.278)$.
복의 $12.5 \%$, 부분회복의 $33.3 \%$, 경도회복의 $85.7 \%$ 로 회복의 정도가 좋지 않을수록 빈도가 높았다(Fig. 3).

\section{고 찰}

돌발성 난청에서 $\mathrm{ABR}$ 검사의 예후인자로서의 유용성에 대 한 몇몇 연구들이 발표되었는데 Wang 등그는 고도 이상의 돌 발성 난청 환자에서 $\mathrm{ABR}$ 검사와 전정유발근전위검사(vestibular evoked myogenic potential)의 파형이 확인되는 환 자군과 확인되지 않는 환자군에서 병의 경과를 비교하였고 $\mathrm{ABR}$ 검사상 상역치 자극에서 $\mathrm{V}$ 파 파형이 확인되는 경우에 청력호전이 유의하게 있음을 보고하였다.

Busaba와 Rauch ${ }^{2}$ 도 돌발성 난청 환자에서 시행한 $\mathrm{ABR}$ 검사상 비정상소견을 보이는 환자군에서 더 낮은 자연회복률 및 스테로이드 치료에 더 낮은 치료반응을 보임을 보고하였 다. 그들은 $\mathrm{ABR}$ 검사상 파형이 지연되는 돌발성 난청 환자 의 경우 좀 더 광범위한 청신경계의 침범을 의미하는 소견으 로 나쁜 예후를 보임을 설명하였다. 이들은 $\mathrm{ABR}$ 검사가 돌 발성 난청의 예후 예측에 도움이 됨을 제시하였지만 이들의 연구에서는 비정상 $\mathrm{ABR}$ 검사소견이 파형의 절대 잠복기 지 연, 파 간의 잠복기 지연, 양이 간 파형의 지연 등을 비정상 결과로 규정하고 이들을 종합하여 비정상군과 정상군으로 나눈 후 비교평가하여 비정상 결과 중 어떤 소견이 돌발성 난 청의 경과에 관계가 있는지, 각 파형의 진폭이나 잠복기가 돌

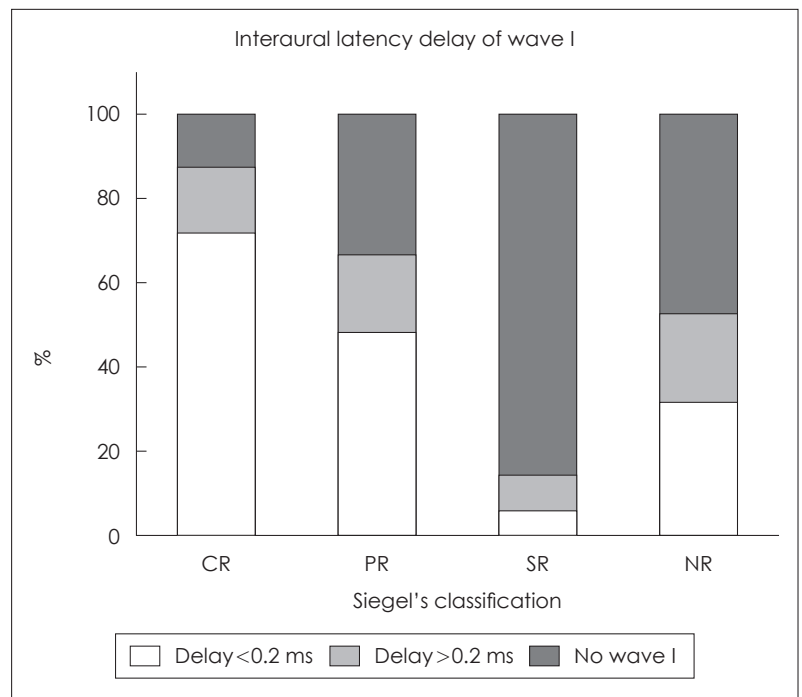

Fig. 3. Composition of each Siegel's group according to wave I delay $\left(\chi^{2}=42.093, p<0.001\right)$. The proportion of interaural latency delay less than $0.2 \mathrm{~ms}$ was predominantly decreasing as less hearing recovery occurred. But, in no-recovery group, the result was unpredictable compared to other group by interaural latency delay of wave I. CR: complete recovery, PR: partial recovery, SR: slight recovery, NR: no recovery. 
발성 난청의 예후에 어떤 영향을 미치는 지에 대해서는 판단 하기 어려웠다.

최근 동물 실험에서 얻은 연구결과에 따르면 $\mathrm{ABR}$ 검사상 I 파형이 청신경의 deafferentiation의 정도를 나타낸다는 보 고가 있었고 ${ }^{910)} \mathrm{Habib}$ 등ํㅡㄴ 든발성 난청의 많은 환자에서 $\mathrm{ABR}$ 검사 중 I파의 부재와 전기와우도 검사상 파형의 부재 가 확인되어 돌발성 난청의 주 병변이 청신경의 말단부에서 기인하지 않을까 추정하였다. Lin 등노 도 ABR 검사의 I파의 절대 잠복기가 돌발성 난청의 예후에 관련된다는 보고를 하 였으며 파형 중 특히 I파가 와우의 최말단에 위치하는 부위 에서 기원하여 돌발성 난청 시 주 병인으로 추측되는 코르티 기관과 밀접해 있어 I파가 예후를 예측하는 데에 도움이 된 다고 추정하였다.

해부학적으로 Schuknecht와 Donovan ${ }^{12)}$ 의 연구에 따르면 돌발성 난청이 있는 12 구의 측두골 소견상 대부분의 병변이 코르티 기관(organ of corti) 및 개막(tectorial membrane)의 위축, 혈관조(stria vascularis)의 위축소견을 보이며 순수하 게 와우 뉴런(cochlear neuron)만을 침범한 경우는 드물게 있음을 보고하였다. 그들은 돌발성 난청 시 해부병리학적으로 청신경의 근위부보다는 와우의 말단부에 주 병변이 있음을 제시하였으며 다양한 해부학적 연구들에서도 Schuknecht와 Donovan ${ }^{12}$ 의 연구결과와 마찬가지로 대부분의 병변이 코르 티기관 및 와우 말단에 위치함을 보고하고 있어 ${ }^{13-15)}$ 이 부위 를 잘 반영하는 검사결과가 돌발성 난청에서 의미가 있지 않 을까 추정케 한다. ${ }^{2,11}$

저자들의 연구에서도 파형의 소실을 고려하지 않은 경우 I 파의 양이 간 잠복기 지연값이 청력호전 정도와 유의한 상관 관계를 보였으며, I파의 파형 소실을 고려한 I파의 양이 간 잠 복기 지연의 정도를 청력회복군과 비교분석한 카이제곱 검정 에서도 의미있는 차이를 보였다. 특히 양이 간 I 파형의 잠복 기 지연이 $0.2 \mathrm{~ms}$ 를 초과하거나 I파의 소실이 있는 경우 청력 호전이 저조함이 확인되었다. 이러한 연구결과를 토대로, 저 자들은 I파의 양이 간 잠복기 지연이 돌발성 난청의 청력호전 을 예측할 수 있는 인자로 추정하였다.

다만 중요한 예후인자인 초기 청력 정도가 $\mathrm{ABR}$ 파형에 미 치는 영향을 배제할 수 없는데 감각신경성 난청 환자에서는 suprathreshold level(역치상 $20 \mathrm{~dB}$ 이상 자극)의 검사에서는 누가현상(recruitment effect)으로 인해 난청 정도에 따른 잠 복기의 영향이 거의 없는 것으로 보고되어 있고 ${ }^{16)}$ 난청 정도 에 따른 잠복기의 보정에 대해서도 이견이 있어 ${ }^{17,18}$ 주병변이 와우로 추정되는 일반적인 돌발성 난청의 경우 초기 청력이 잠복기에 유의한 변화를 초래하지 않는다고 고려된다. 하지 만 돌발성 난청의 경우 와우성 난청 외에 $\mathrm{ABR}$ 상 잠복기에
영향을 줄 수 있는 신경성 난청(neural hearing loss)이 함께 혼재할 수 있고 고도 난청 환자 및 농 환자에서는 $90 \mathrm{~dB}$ 의 자극이 충분한 강자극이 아니므로 누가현상이 난청의 정도 를 극복하기는 어려운 한계가 있을 것으로 생각된다. 하지만 본 연구에서 초기 난청 정도는 wave I의 절대 잠복기와 양이 간 잠복기 차이와는 상관관계를 보이지 않으나 wave I만이 청력호전과 의미있는 상관관계를 보여 이것이 단순히 초기 난청 정도에 따른 결과로 해석하기는 어렵다고 판단된다.

본 연구에서 분석에 포함하지는 않았지만, 돌발성 난청의 발병 당시 어지럼증을 동반한 환자는 33명(29.2\%)이었으며, 과거력으로 당뇨 환자가 23명(20.4\%), 고혈압 환자가 28명 (24.8\%), 고지혈증 환자가 9명(8.0\%) 포함되었다. 본 연구 대 상자들에서 회복 정도에 대한 각각의 인자들의 영향은 일변 량 회귀분석에서 모두 유의하지 않았다 $(p>0.05)$.

한편 본 연구에서 Siegel에 따른 분류를 하였을 때 회복이 안 되는 군으로 갈수록 I파의 양이 간 잠복기 지연이 커지고 I 파형이 소실된 경우가 많은 양상을 보이나 청력 회복이 없 는 불변(no improvement)군에서는 오히려 부분회복의 결과 와 차이가 없는 소견으로 예측이 잘 맞지 않았다. 본 연구에 서는 청력회복 정도가 불변의 경우는 $\mathrm{ABR}$ 파형으로는 결과 를 예측하기 어려울 것으로 판단되었는데 이에 대해서는 추 가적인 연구가 있어야 할 것으로 보인다.

상기의 검사는 후향적 진료기록을 통한 연구로 이로 인한 한계가 있을 것으로 생각되며 $\mathrm{ABR}$ 파형의 특성 중에서도 진폭에 대한 연구가 이루어지지 않았다. 또한 I파의 경우 파 형의 진폭이 작아 주관적으로 판정되며 소실율이 많아 그에 따른 한계가 있을 것으로 보인다. 하지만 동일한 치료를 시행 받은 비교적 많은 수의 환자를 대상으로 동일한 검사환경에 서 검사를 시행하였으며 임상적으로 비교적 많이 시행되고 있는 $\mathrm{ABR}$ 검사의 돌발성 난청의 예후인자로서의 역할을 확 인할 수 있어 의미가 있다. 또한 돌발성 난청의 주 병인이 와 우 말단에 위치함을 주장하는 기존의 연구들을 뒷받침하는 소견이라 생각된다. 추후 좀 더 많은 환자를 대상으로 한 연 구가 보완이 되어야 할 것이다.

\section{ORCID}

SungHee Kim https://orcid.org/0000-0002-3844-2213

\section{REFERENCES}

1) Kim CS, Jun SH, Kim LS, Kim HK. Clinical study on auditory brainstem response. Korean J Otorhinolaryngol-Head Neck Surg 1985;28(3):279-83.

2) Busaba NY, Rauch SD. Significance of auditory brain stem response and gadolinium-enhanced magnetic resonance imaging for idiopathic sudden sensorineural hearing loss. Otolaryngol Head 
Neck Surg 1995;113(3):271-5.

3) Wang CT, Huang TW, Kuo SW, Cheng PW. Correlation between audiovestibular function tests and hearing outcomes in severe to profound sudden sensorineural hearing loss. Ear Hear 2009;30(1): $110-4$.

4) Lin HC, Chou YC, Wang CH, Hung LW, Shih CP, Kang BH, et al. Correlation between auditory brainstem response and hearing prognosis in idiopathic sudden sensorineural hearing loss patients. Auris Nasus Larynx 2017;44(6):678-84.

5) Fisch U. Management of sudden deafness. Otolaryngol Head Neck Surg 1983;91(1):3-8.

6) Clemis JD, Mitchell C. Electrocochleography and brain stem responses used in the diagnosis of tumors. J Otolaryngol 1977;6(6): 447-59.

7) Rosenhamer HJ, Lindström B, Lundborg T. On the use of clickevoked electric brainstem responses in audiological diagnosis. IV. Interaural latency differences (wave V) in cochlear hearing loss. Scand Audiol 1981;10(2):67-73.

8) Selters WA, Brackmann DE. Acoustic tumor detection with brain stem electric response audiometry. Arch Otolaryngol 1977;103(4): 181-7.

9) Kujawa SG, Liberman MC. Adding insult to injury: Cochlear nerve degeneration after "temporary" noise-induced hearing loss. J Neurosci
2009;29(45):14077-85.

10) Stamper GC, Johnson TA. Auditory function in normal-hearing, noise-exposed human ears. Ear Hear 2015;36(2):172-84.

11) Habib SS, Husain A, Omar SA, A1 Drees AM. Brainstem auditory evoked potentials and electrocochleographic findings in patients with idiopathic sudden sensorineural hearing loss. J Coll Physicians Surg Pak 2011;21(7):415-9.

12) Schuknecht HF, Donovan ED. The pathology of idiopathic sudden sensorineural hearing loss. Arch Otorhinolaryngol 1986;243(1):1-15.

13) Ishii $T$, Toriyama M. Sudden deafness with severe loss of cochlear neurons. Ann Otol Rhinol Laryngol 1977;86(4 Pt 1):541-7.

14) Gussen R. Sudden deafness of vascular origin: A human temporal bone study. Ann Otol Rhinol Laryngol 1976;85(1 Pt 1):94-100.

15) Nomura Y, Hiraide F. Sudden deafness. A histopathological study. J Laryngol Otol 1976;90(12):1121-42.

16) Durrant JD, Fowler CG. ABR protocols for dealing with asymmetric hearing loss. Am J Audiol 1996;5:5-6.

17) Selters W, Brackmann D. Brainstem electric response audiometry in acoustic tumor detection. In: House WF, Luetje CM, editors. Acoustic Tumors. Baltimore: University Park Press; 1979. p.225-35.

18) Cashman MZ, Stanton SG, Sagle C, Barber HO. The effect of hearing loss on ABR interpretation: Use of a correction factor. Scand Audiol 1993;22(3):153-8. 